\title{
Using a Musical to Teach About the Patient Experience
}

\author{
Tom Willner* \\ Creating innovative solutions for education, Georgia State University, Georgia
}

Submission: February 21, 2018; Published: February 26, 2018

"Correspondence Address: Tom Willner, Creating innovative solutions for education, Georgia State University, Rensselaer Polytechnic Institute, Atlanta, Georgia, Email: tom.willner@gmail.com

\section{Introduction}

When I turned thirty years old, something happened that changed the course of my life - I was diagnosed with testicular cancer. Up until that point, I had generally been very healthy. I had never even broken a bone. I was living a charmed life; I had a rewarding technology career, growing success as a musician and composer, and a loving wife thinking of starting a family. One day a lump appeared on my body, and before long I found myself faced with my own mortality.

\section{Discovery}

My wife, Allyson, and I were DINKs - Dual Income No Kids - but were already having serious discussions about starting a family. We lived a pretty "Type A" lifestyle; we both enjoyed our work, each travelling around the country to different destinations, then cherishing our weekends together that were always too short. One summer, we travelled to Allyson's company retreat. While there, during a shower, I discovered a lump on a part of my body no man ever wishes to find one. I talked to Allyson about it, but basically didn't think much about it myself. Looking back, I was clearly in denial. Fortunately, my wife set up an appointment for me with an urologist when I returned home.

\section{Realization}

A few weeks later, my urologist scheduled an orchiectomy to remove my testicle and have the mysterious mass biopsied. I still didn't realize what was happening, and it wasn't until Allyson used the word "cancer" that it hit me. It was less than a year before that I had lost my father to prostate cancer. I freaked out, researching every bit of information about testicular cancer I could find. I had the orchiectomy, the first surgery I have ever had, and then proceeded to recuperate and stress for the next six days waiting for the pathology report. Waiting for a "verdict" for six days was excruciating. Unfortunately, the report confirmed my worst fear: I had cancer.

\section{Cut It Out}

The biopsy revealed a particularly aggressive form of nonseminoma testicular cancer of mixed type, but predominantly embroynal that had invaded the vascular and lymphatic regions. So while my experience with this tumor so far was not little more than a small lump that wasn't particularly painful nor causing me any apparent symptoms, what lurked inside appeared to be much more precarious. My urologist and I discussed my options at this point, which were surgery or "watch and wait." CT Scans had revealed a few suspect masses in my abdomen, and we could either remove them with a procedure known as a Retroperitoneal Lymph Node Dissection (RPLND) to biopsy them, or continue to watch them with periodic scans for any indication of spread. I decided to play the odds; having the surgery increased my chances of survival. However, the surgery turned out to be one of the hardest weeks of my life - a lot of pain, the nefarious Nasal Gastric (NG) tube, and having to relearn how to walk and eat. I spent nearly a week in the hospital and several months recovering from that surgery. Fortunately, the biopsies came back negative. We breathed a sigh of relief, and felt like this torture was finally over (Figures 1 \& 2).

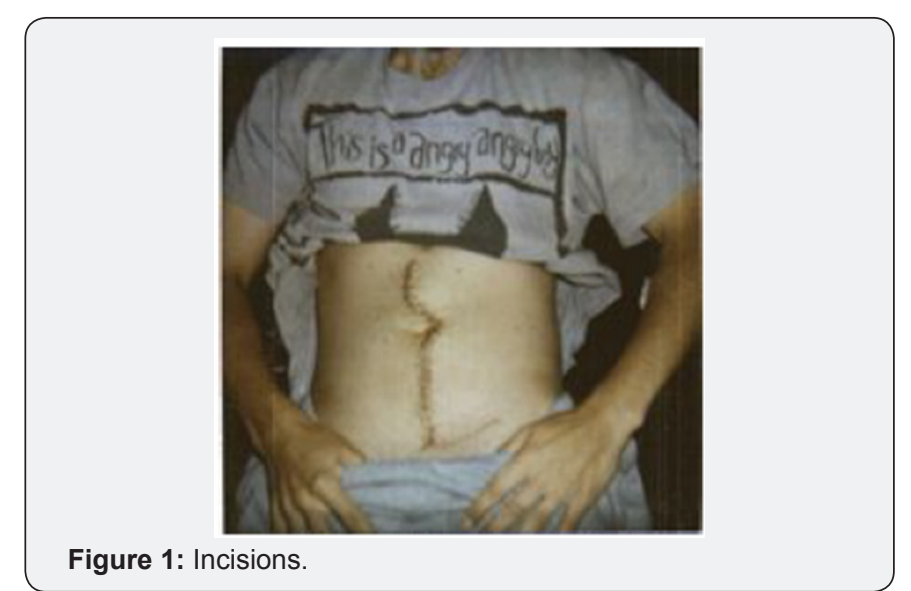




\section{Cancer Therapy \& Oncology International Journal}

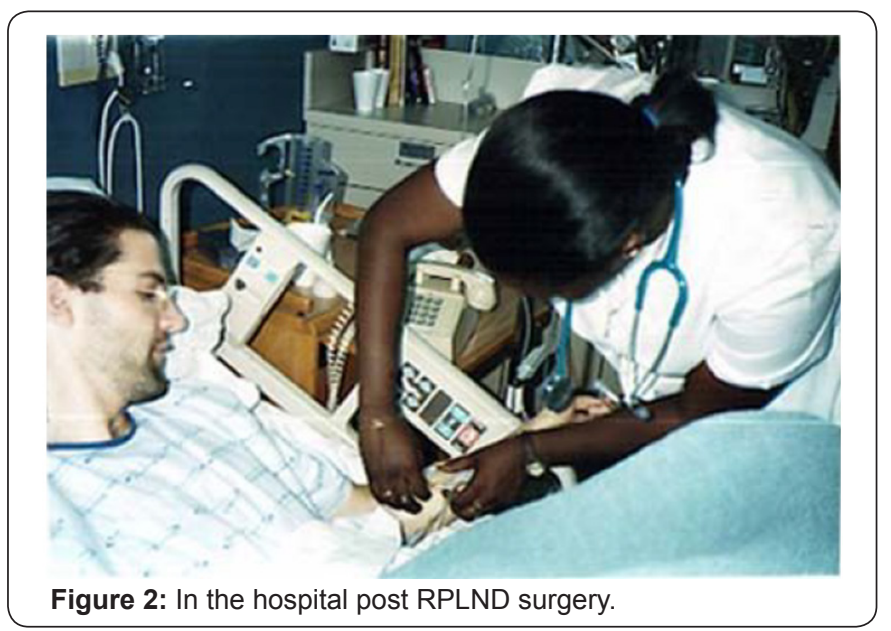

\section{Identity}

Discovering I had testicular cancer while discussing starting a family really brought on a new sense of urgency. In fact, I really felt my whole masculinity being challenged. Knowing before the RPLND that there was a risk I would no longer be able to conceive naturally, I made several deposits at a fertility clinic. We also decided to throw caution to the wind and attempt to get pregnant the old fashioned way before the surgery. As it turned out, I not only got the side effect, but a significant version of it - lack of emission. However, we also discovered that my wife did get pregnant. Unfortunately, during my recovery, my wife suffered a miscarriage. Between cancer, side effects, pregnancy, and miscarriage, we were on an emotional roller coaster ride. I decided to grow a beard for the first time in my life, perhaps in protest over the new challenges to my masculinity. I also decided to cut my hair short, which was long enough to wear in a ponytail at the time, and donate the hair to Wigs for Kids, an organization that provided wigs of

real hair to children who lost their hair from chemotherapy. I also bleached my new short hair blonde. I was truly experimenting with my new identity. My wife said she enjoyed sleeping with this new guy. A friend of mine, in shock after seeing my new look, said that he really wanted to be around for my mid-life crisis.

As a way to deal with all I was going through, I began to write daily in a journal. One day, I got the idea to write a musical called "Turning Thirty" all about my cancer experience. I wrote the title of the show, the names of all the main characters, and the titles to about seven of the songs all at once. I had never gotten a creative idea like that so clearly before. It was as if I was a vessel and it all just poured through me. During my recovery, the songs began flowing out quickly. As the months passed, the follow up CT scans became routine. My wife and I decided to try In Vitro Fertilization (IVF) and as luck would have it, Allyson became pregnant again. We planned a vacation to Greece and Turkey, and looked forward to our new lives.

\section{Recurrence}

I had what I felt was going to be another routine follow up visit where I would get my clean bill of health, then I could head off to vacation. What I learned instead, six months after the RPLND, was that a new mass had formed in my lung. It was indeed a metastasis of my testicular cancer. In a fog and sobbing after receiving the news, I called Allyson, who at first thought I was joking.

She was out of town and immediately hopped on a plane to come home. With input from my urologist and thoracic surgeon, we scheduled the surgery a week later so that we could still go on our vacation. We did our best to enjoy ourselves, Allyson dealing with morning sickness, me dealing with my own mortality. Fortunately, we were with great friends in a great place, and we knew had no choice but to live fully in every moment we had. When we returned, I had a lung thoracotomy, also known as a wedge resection. This time, I had a successful epidural, which I found to be a miraculous form of pain control. I was in intensive care after the surgery with over thirty tubes and wires coming out of or attached to my body, and I felt little to no pain. I spoke to my oncologist, who agreed to a short three week recovery period before starting me on chemotherapy (Figure 3).

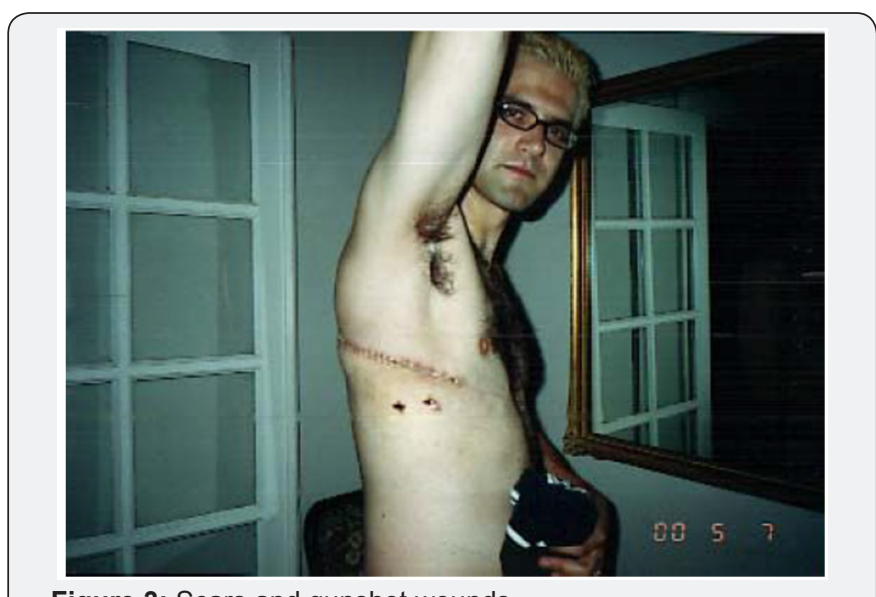

Figure 3: Scars and gunshot wounds.

Poison

Three weeks later, I began a series of four rounds of chemotherapy. Each round was three weeks long, and consisted of BEP, or Bleomycin, Etoposide, and Cisplatin, each one effectively a poison designed to kill these fast growing cells in your body. The first week of every round was horrible. I spent the first half of each round nauseous and miserable, losing a little bit of every sense - seeing, hearing, smelling, tasting, and touching - in the process. I was taking medicines to counteract the side effects of medicines to counteract the side effects of medicines. My white blood cell count went down to dangerously low levels, such that I was incapable of fighting off infections. I had to give myself shots to stimulate white blood cell production, but I got such intense pain in my bones from it, that I had to stop and try other methods.

Undergoing chemotherapy was by far the worst time of my life. I did, however, meet some of the most compassionate people I know - the infusion centre nurses. I am forever grateful to them and all of the people in healthcare who devote their lives to the well-being of others. After my first round was over, I noticed that 


\section{Cancer Therapy \& Oncology International Journal}

I could easily pull out my hair. I went straight to my hairdresser, who buzzed it all off on the spot. Before long, I was completely bald. I also lost my eyebrows, eyelashes, and almost every hair I had anywhere on my body (Figure 4).

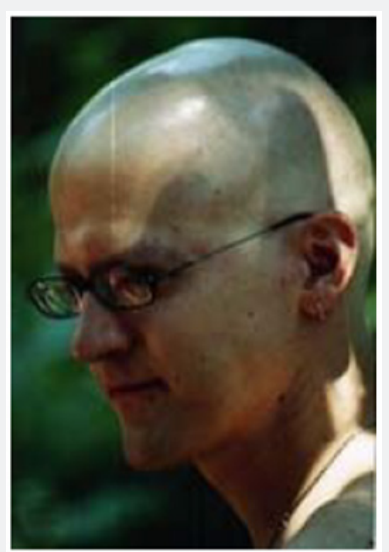

Figure 4: Loss of Eyebrows, Eyelashes, and almost every hair on body.

It was a gruelling three months, but finally, about one year after my original diagnosis, I completed my treatment.

\section{New Perspective}

I am now an 18 year cancer survivor. I have been down a path that changed my life. No longer do I look at things the same way. I now have a healthy respect for every visit to the doctor, and I never miss my annual exam. I realize that every single living, breathing moment is one to be savored, no matter whether it is easy or difficult, good or bad, right or wrong. The hardest moments in my life now seem to pale in comparison to the time when I was fighting to stay alive, using knives and poison. I don't know what will be the end of this story; I just hope it comes many, many years from now.

\section{Writing a Musical about Cancer}

As a musician and songwriter, composing songs and creating the musical about my experience truly helped me get through my cancer diagnosis and treatment. I wrote and recorded many of the songs during my treatment as a way to express the physical and emotional struggles I experienced. About a year post treatment, I completed the musical. For a number of years, I didn't do much with it, but as I approached turning forty years old, I decided it was time to get Turning Thirty out there! I summoned the help of some fellow musicians, actors, and friends involved in theater to put on the debut performance of Turning Thirty, The Musical as a staged reading in 2008. The show continued to develop over the next two years with two more staged readings and a concert performance. These four performances raised thousands of dollars for charities, and as audiences continued to grow, I launched a successful crowd-funding campaign that raised $\$ 10,000$ for a professional workshop and showcase. In 2013, that showcase was presented at the Theatrical Outfit in downtown Atlanta to a standing ovation. An actor in the show mentioned to me how great he thought it would be to present the show to healthcare workers to teach about the patient experience.

As news spread about the show, I received a phone call from Anne McSweeney, a social worker who had created a company that presented innovative CEU classes for nurses, social workers, case managers, and other healthcare professionals. We teamed up to form Center Stage Education, to use the show to teach about the patient experience. In addition to performances at numerous CEU accredited classes, this unique musical educational experience has been featured in 2016 at the World Congress for Continuing Professional Development in San Diego, CA and the 2017 Alliance for Continuing Education in the Health Professions Annual Conference in San Francisco, CA. I continue to speak and perform, most recently

teaming up with Medscape at the 2018 Alliance Annual Conference in Orlando, FL.

The challenge of my cancer experience truly strengthened who I am and inspired me to do more. My wife and I now have three healthy and happy children. I continue to use my skills with technology to help student success at Georgia State University. I have also become a patient advocate, using my experience and musical to hopefully inspire and to teach about the patient experience, patient centered care, and shared decision making. The journey here has been exciting (Figure 5).

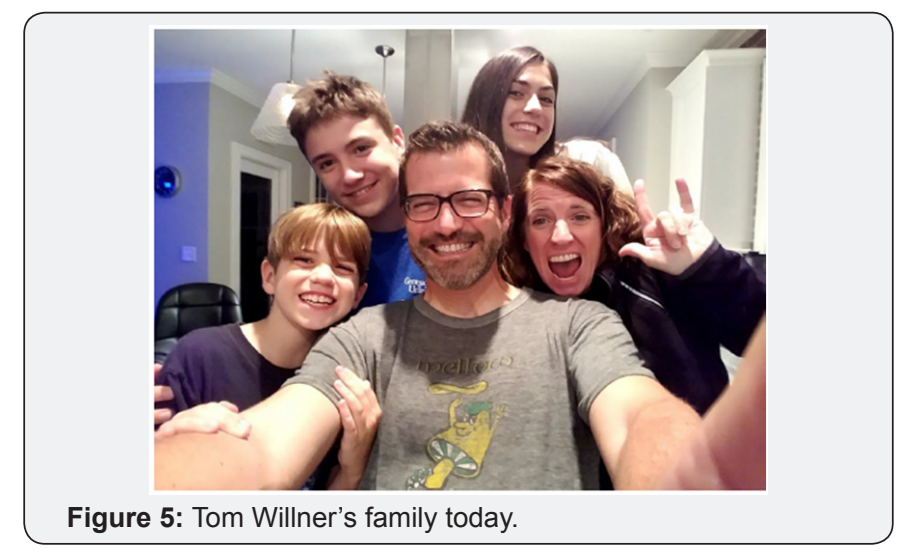




\section{Cancer Therapy \& Oncology International Journal}

This work is licensed under Creative

Commons Attribution 4.0 License

DOI: 10.19080/CTOIJ.2018.09.555769
Your next submission with Juniper Publishers will reach you the below assets

- Quality Editorial service

- Swift Peer Review

- Reprints availability

- E-prints Service

- Manuscript Podcast for convenient understanding

- Global attainment for your research

- Manuscript accessibility in different formats ( Pdf, E-pub, Full Text, Audio)

- Unceasing customer service

Track the below URL for one-step submission https://juniperpublishers.com/online-submission.php 